RESEARCH ARTICLE

\title{
A NEW SPECIES OF AQUATIC ORIBATID MITE "HYDROZETES CRASSIPES SP. N." (FAMILY: HYDROZETIDAE) FROM SOHAG GOVERNORATE, EGYPT
}

\author{
Asmaa N. Mustafa*; Somaia A. Ramadan \\ Zoology Department, Faculty of Science, Sohag University, Sohag, Egypt
}

\begin{tabular}{l} 
Article History: \\
Received: 20 December 2021 \\
Accepted: 14 January 2022 \\
Published Online: \\
\hline 28 January 2022 \\
Keywords: \\
Acari \\
Egypt \\
Hydrozetes \\
Hydrozetidae \\
Oribatida \\
*Correspondence: \\
Asmaa Mustafa \\
Zoology Department \\
Faculty of Science \\
Sohag University \\
Sohag, Egypt \\
E-mail: \\
asmaa.ahmed1 @ science.sohag. \\
edu.eg
\end{tabular}

Article History:

Received: 20 December 2021

Accepted: 14 January 2022

Published Online:

28 January 2022

Keywords:

Egypt

Hydrozetes

Hydrozetidae

*Correspondence:

Asmaa Mustafa

Zoology Department

Faculty of Science

Sohag University

Sohag, Egypt

asmaa.ahmed1@science.sohag. edu.eg

\begin{abstract}
A new species of oribatid mite in the genus Hydrozetes (Suborder: Oribatida, Family: Hydrozetidae) is described in the current study for the first time from Egypt. The aquatic oribatid mite, Hydrozetes crassipes sp. n., was collected from roots of the aquatic plant, Eichhornia crassipes, floating in the River Nile, Sohag Governorate, Egypt. The descriptive characters of the present species are in accordance with those of the family and genus such as: the dorsum of individuals is smooth or finely punctate, never granulated or rugose, the legs are monodactylous, the prodorsum of the body is characterized with transverse and longitudinal ridges, the exobothridial setae are mostly very short; and trichobothria (bothridium and sensillus) is present. Hydrozetes crassipes sp. n. differs from the other published species in certain characters such as: the humeral regions are supported by two pairs of sclerotized plates, which are tapering inwardly towards the prodorsal lamellae, seven sclerotized opisthosomal plates, the longitudinal distance between setae of $(l-)$ and $(d-)$ series is not equal, the presence of five pairs of genital setae $(g l-g 5)$, and three pairs of genital discs.
\end{abstract}

\section{INTRODUCTION}

Hydrozetids are oribatids that composed of freshwater species ${ }^{[1]}$. The genus Hydrozetes of oribatid mites lives in aquatic habitats like ponds, lakes, and rivers ${ }^{[2-6]}$. The identification and description of Hydrozetes species were studied from different regions all over the world: South Africa, Hydrozetes capensis $^{[7]}$; Europe, Hydrozetes confervae, Hydrozetes lacustris, Hydrozetes lemnae, Hydrozetes octosetosus, Hydrozetes parisiensis, and Hydrozetes thienemanni ${ }^{[8]}$; Poland, Hydrozetes longisetosus ${ }^{[9]}$; Philippines, Hydrozetes mindanaoensis ${ }^{[10]}$, and Ecuador, Hydrozetes behanpelletierae ${ }^{[6]}$. The adults of published species of genus Hydrozetes differ from each other mainly by the shape of the bothridium and sensillus, the shape and number of notogastral setae, the number of genital setae, the epimeral setal formula, the shape of setae on the legs near the claw, and the number of claws on leg $\mathrm{IV}^{[6,9,10]}$. The present paper aims to illustrate and describe the morphology of the adult of aquatic oribatid mite, Hydrozetes crassipes sp. n. collected from roots of the floating aquatic plant, Eichhornia crassipes, in River Nile, Sohag Governorate, Egypt.

\section{MATERIAL AND METHODS}

The adult specimens of the present species, Hydrozetes crassipes sp. n., were collected from roots of the floating plant, Eichhornia 
crassipes (water hyacinth). The site of collection located on the western bank of the River Nile $\left(26^{\circ} 21^{\prime} \mathrm{N}\right.$ and $\left.31^{\circ} 53^{\prime} \mathrm{E}\right)$ at Sohag, Egypt. The specimens were mounted in lactic acid and a droplet of Hoyer's medium for illustration, identification, and measurements of the present species. The images were obtained using JEOL 5300 Scanning Electron Microscope (JEOL Ltd., Akishima, Tokyo, Japan).

- Holotype: female (448 $\mu \mathrm{m}$ in length)

- Paratypes: 18 females

Holotype and paratypes of the present species are deposited in the Zoology Department, Faculty of Science, Sohag University.

Drawings were done with the aid of a camera Lucida. The body length was measured in lateral view, from the tip of rostrum to the posterior edge of the notogaster. Notogastral width refers to its maximum width in dorsal aspect. All body measurements were taken by calibrated eye piece and presented in micrometres. Formulas for leg setation are given in parentheses according to the following sequence: trochanter-femur-genu-tibia-tarsus (famulus included). Formulas for leg solenidia are given in square brackets according to the following sequence: genutibia-tarsus.

The present oribatid mite, Hydrozetes crassipes sp. n., was identified according to the keys included in the previously published papers ${ }^{[5,6,10-13]}$. General morphological terminology and abbreviations of the oribatid mite setae are developed by Luxton $^{[13]}$, and those for leg setal nomenclature by Bayartogtokh and Ermilov $^{[6]}$ and Norton ${ }^{[14]}$.

\section{RESULTS}

\section{Description of the Hydrozetes crassipes} sp. $n$.

The body of the present species consists of two regions, prodorsum ( $p r)$ and notogaster (no). The prodorsal region has distinct trichobothria (bothridium and sensillus), two narrow lamellae (la), two pairs of prodorsal ridges (tua, tup), and short smooth setae.
The notogaster (no) is oval in shape with lenticulus (lent), two pairs of sclerotized plates in the humeral regions, seven sclerotized opisthosomal plates, and thirteen pairs of long and smooth simple setae. The anogenital area has five pairs of genital setae ( $g 1-g 5)$, one pair of aggenital setae (ag), two pairs of anal setae (an1, an2), and three pairs of adanal setae (adl-ad3) (Figure 1a,b).

The body is oval in shape, reddish-brown in colour and with medium size (about $448 \mu \mathrm{m} \times 272 \mu \mathrm{m})$ (Figure 1a). The prodorsum $(p r)$ is measured about $120 \mu \mathrm{m}$ and $152 \mu \mathrm{m}$ in length and width, respectively. It is triangular in shape with rounded rostrum. The prodorsal region carries two pairs of prodorsal ridges (tua, tup), two narrow lamellae (la), four pairs of simple smooth setae (ro, le, in, ex), and one pair of distinct trichobothria (bothridium and sensillus). Transverse (tua) and longitudinal (tup) prodorsal ridges are well developed and located lateral to lamellae. Rostral setae (ro) are smooth, curved outwardly and situated anteriorly on prodorsum. Lamellar setae (le) are tiny, smooth and located at apex of lamellae. Interlamellar setae (in) are tiny, smooth and located on basal part of lamellae in front of bothridium. Exobothridial setae (ex) are fine, smooth and lie posterior to the bothridium. Each bothridium (bo) is oval in shape and located near to basal part of lamellae. Each sensillus (ss) is smooth with short stalk and clavate head (Figures 1a and 2a,d,f).

Each pedipalp $(p)$ consists of five segments (trochanter, femur, genu, tibia, and tarsus) with typical setation 0-2-1-3$9(+\omega)$. Palpal trochanter is trapezoidal in shape with concave anterior margin and without setae, while palpal femur is the longest one and carries two long and smooth setae $\left(l^{\prime \prime}, v^{\prime \prime}\right)$. Palpal genu is rectangular in shape and bears one long and smooth seta $(d)$. Palpal tibia is slightly square in shape and carries two simple setae [one short $\left(l^{\prime \prime}\right)$ and one long $\left.\left(l^{\prime}\right)\right]$ and only one pectinate seta $(d)$. 

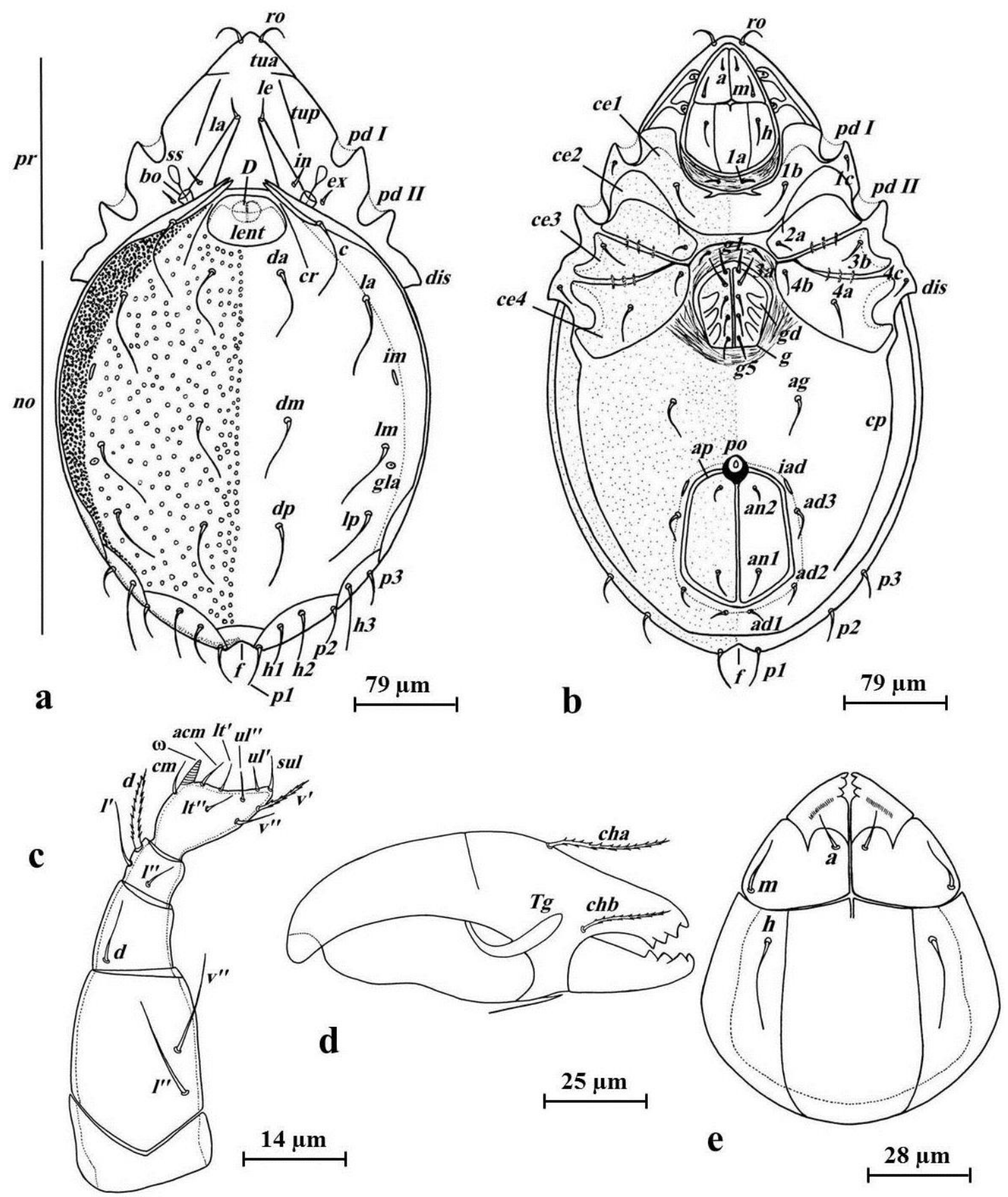

Figure 1: Camera Lucida drawings of the adult female Hydrozetes crassipes sp. n. showing: (a) dorsal view, (b) ventral view, (c) pedipalp, (d), chelicera, and (e) subcapitulum. Single prime (') marks setae on the anterior and double prime (') marks setae on the posterior side of a given palp segment.

Palpal tarsus is nearly cone-like in shape and carries nine different sized setae [eight smooth (cm, acm, $l t^{\prime}, l t^{\prime \prime}, u l^{\prime}, u l^{\prime \prime}$, sul, $\left.v^{\prime \prime}\right)$ and one pilose $\left.\left(v^{\prime}\right)\right]$ and one solenidion $(\omega)$ (Figures 1c, 2h and 3a). Each chelicera (ch) is chelate-dentate with a base and two chelate digits (one fixed and the other movable). Each digit bears four teeth. The base of chelicera is nearly elongated with two distinct barbed setae (cha, chb). Trägårdh's organ $(T g)$ of each chelicera is elongated and rounded distally (Figures 1d, $2 \mathrm{~h}$ and $3 b$ ). 

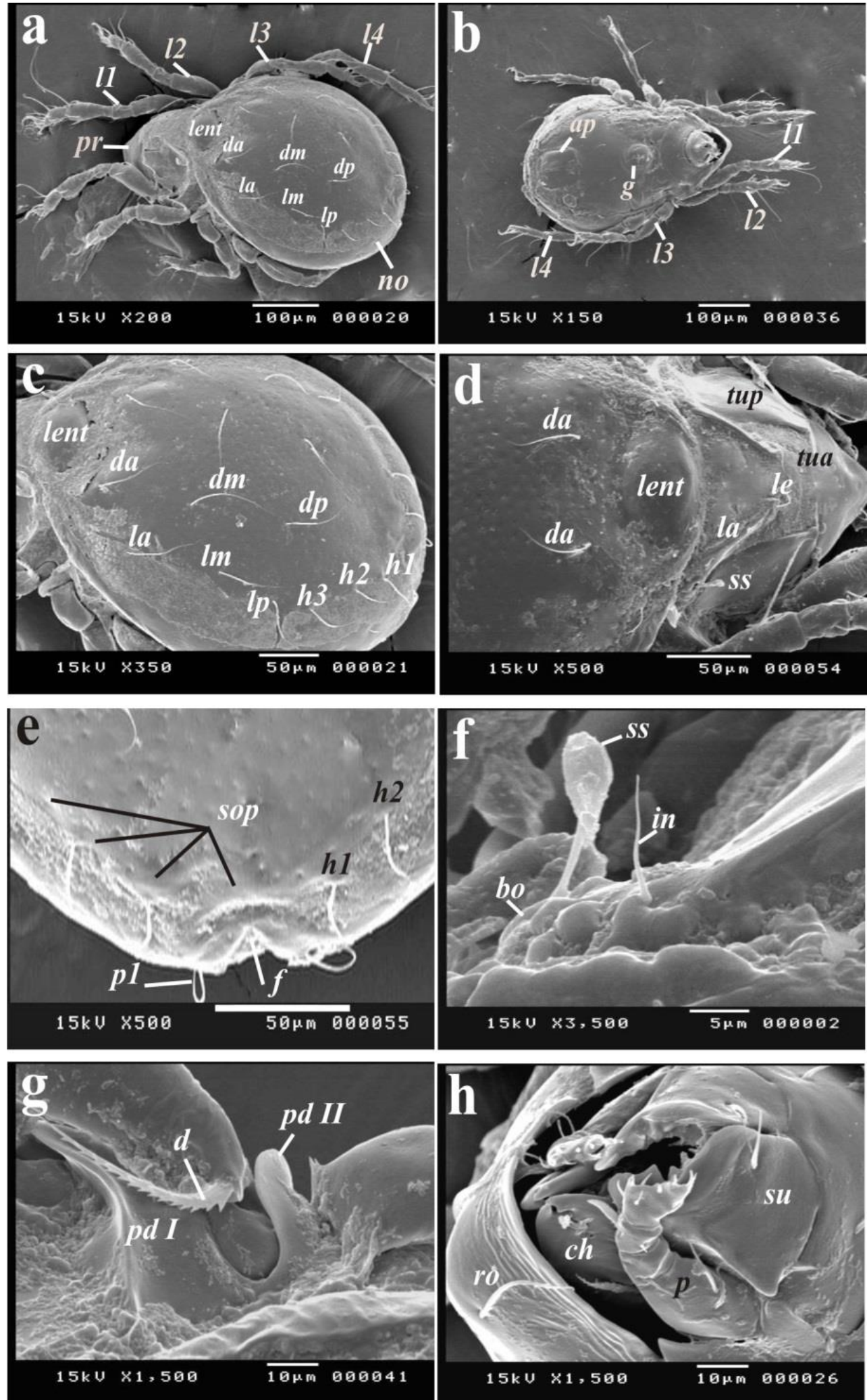

Figure 2: Scanning electron micrographs of adult female Hydrozetes crassipes sp. n. showing: (a) dorsal view, (b) ventral view, (c) higher magnification of (a) showing lenticulus and notogastral setae, (d) higher magnification of (a) showing lenticulus and prodorsum, (e) posterior end of notogaster showing longitudinal furrow and sclerotized opisthosomal plates, (f) clavate sensillus and interlamellar seta, (g) pedotecta I and II, and (h) subcapitulum, pedipalp and chelicerae. 

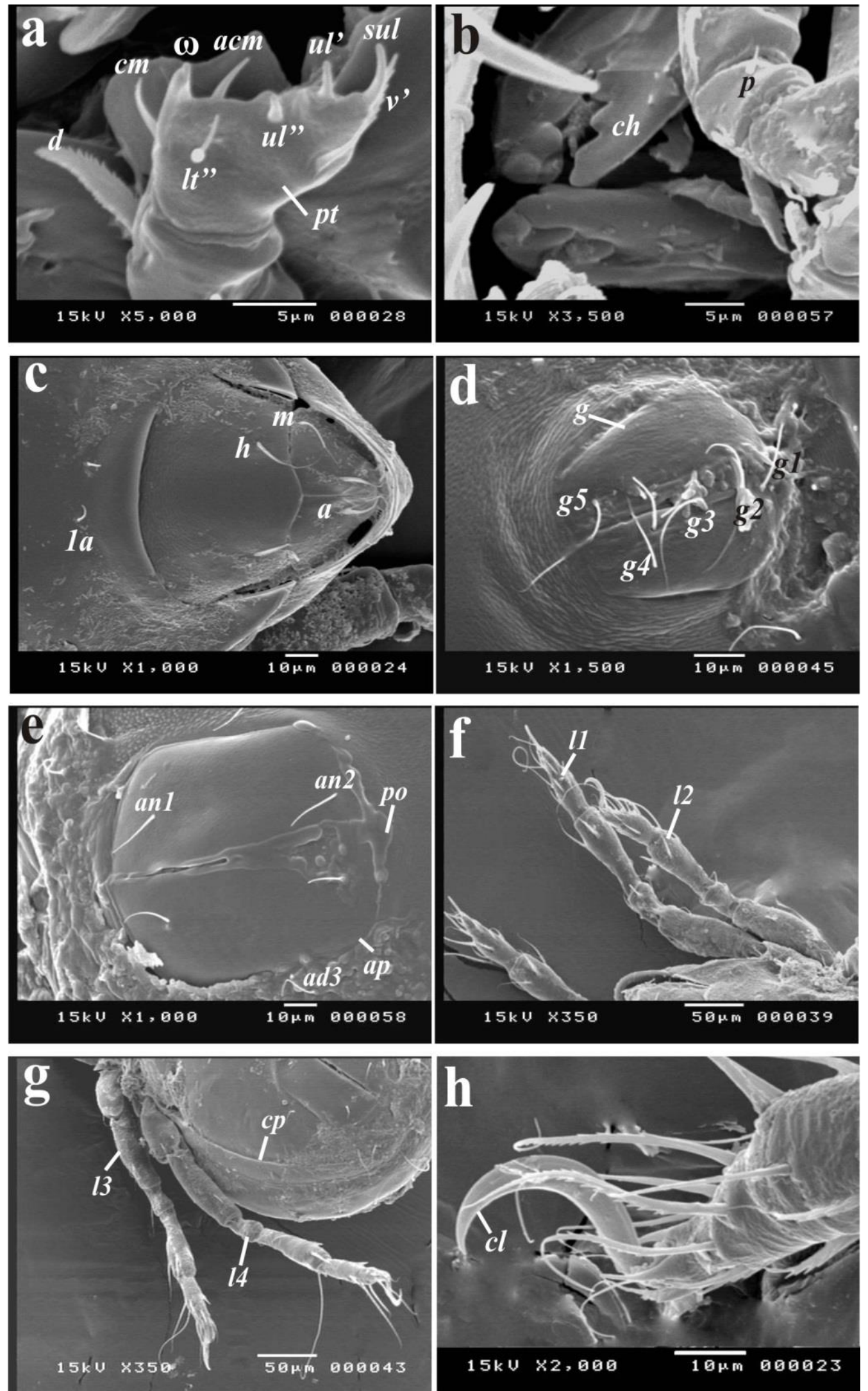

Figure 3: Scanning electron micrographs of adult female Hydrozetes crassipes sp. n. showing: (a) higher magnification of (2h) showing palpal tarsus setae and palpal solenidion, (b) chelicerae, (c) subcapitulum and subcapitular setae, (d) genital region, (e) anal region, (f) legs I and II, (g) legs III, IV, and circumpedal carinae, and (h) tarsus of leg II. 
The notogaster (no) is oval in shape with anterior convex margin and measured about $328 \mu \mathrm{m}$ in length and $272 \mu \mathrm{m}$ in width (Figure 1a). The posterior margin of notogaster is characterized by presence of longitudinal furrow $(f)$. In the dorsal aspect, the notogaster has lenticulus (lent), dorsophragmata $(D)$, one pair of cristae $(c r)$, two pairs of sclerotized plates in the humeral regions, seven sclerotized opisthosomal plates, thirteen pairs of long and smooth setae, one pair of lyrifissures (im), and one pair of opisthonotal gland openings ( $\mathrm{lla}$ ). The lenticulus (lent) is well visible, clear, nearly rounded and located in the anterior part of the notogaster behind the prodorsum. Dorsophragmata $(D)$ are oval in shape and connected medially. Each crista (cr) is located lateral to lenticulus in the anterior region of the notogaster. The humeral regions supported by two pairs of sclerotized plates which tapering inwardly towards the prodorsal lamellae. The seven sclerotized opisthosomal plates decreased gradually towards the humeral regions. Three pairs of these plates located in the lateral margins of notogaster, while the remaining one found in the central area of notogaster (Figures 1a and $2 \mathrm{a}, \mathrm{c}, \mathrm{d}, \mathrm{e})$.

The notogastral setae are long, simple, and smooth, including only one pair of setae $c$, three pairs of setae in $l$-series, three pairs of setae in $d$-series, three pairs of setae in $h$-series, and three pairs of setae in $p$-series (Figures 1a). Each seta (c) situated lateral to cristae in the humeral regions, while seta $(l m)$ located anterior to opisthonotal gland openings $(\mathrm{gla})$. The setae in $l$ - and $d$-series are arranged in longitudinal rows, while setae in $h$ - and $p$-series are positioned on the posterolateral margin of notogaster. Longitudinal distance between setae of $l$ - and $d$-series is not equal. These setae are described in details as follows: setae $(\mathrm{lm})$ and $(\mathrm{dm})$ are closer to setae $(l p)$ and $(d p)$ than to setae (la) and $(d a)$, respectively. Lyrifissure (im) located between setae $(l a)$ and $(l m)$. The opisthonotal gland openings ( $g l a)$ are located lateral to setae $(l m)$. The cuticle of the lateral margins of notogaster is densely microfoveolate, while the central region of notogaster is ornamented with sparse foveolae (Figures 1a and 2a,c,d,e).

The ventral aspect displays subcapitulum, two groups of coxal epimerae, and anogenital area. Subcapitulum is longer than wide, surrounded by striation, and measured about $91 \mu \mathrm{m}$ in length and $78 \mu \mathrm{m}$ in width. Subcapitulum carries three pairs of short smooth setae $(h, m, a)$ and two groups of adoral setae, which located in front of setae (a) (Figures 1e, 2h, and 3c). The first group of coxal epimerae contains epimerae I and II, while the second one includes III and IV. The epimeral setae are paired in number and setal formula on each side of epimerae from I- IV is 3-1-2-3. All epimeral setae ( $1 a$, $1 b, 1 c, 2 a, 3 a, 3 b, 4 a, 4 b, 4 c)$ are smooth and located as follows: setae (la) behind subcapitulum, $(1 b)$ on coxal epimerae I, (1c) on apical part of pedotecta I, $(2 a)$ on coxal epimerae II, $(3 a)$ anterolateral of genital region, $(3 b)$ on coxal epimerae III, $(4 a, 4 b)$ on coxal epimerae IV, and (4c) on pedotecta IV (Figures $1 b$ and 2b). Discidia (dis) are triangular in shape and extended externally above the coxae of leg IV. Circumpedal carinae $(c p)$ are semioval in shape, directed to discidia anteriorly, and interrupted behind the anal aperture (Figures $1 \mathrm{~b}$ and $3 \mathrm{~g}$ ).

Anogenital area includes anal and genital regions. The genital region includes genital opening, pair of genital plates, and pair of aggenital setae. The genital opening is elongated, slit-like structure, and guarded by one pair of genital plates. The genital plates $(g)$ are elongated in shape and surrounded by striation. Each genital plate carries five pairs of simple setae ( $g l-g 5)$ and three genital discs $(g d)$. The aggenital setae $(a g)$ are simple, smooth and located laterally between anal and genital plates (Figures 1b, 2b, and 3d).

The anal region includes anal opening, pair of anal plates, three pairs of adanal setae, preanal organ, and pair of lyrifissures. The anal opening is long slit-like structure and surrounded by pair of anal plates. The 
anal plates (ap) are elongated in shape and carry two pairs of simple setae (an1, an2), which situated in the anterior and posterior parts. The adanal setae ( $a d 1, a d 2, a d 3)$ are simple and smooth. Adanal setae (ad3) situated laterally, while setae $(a d l)$ and (ad2) situated posteriorly to anal plates. The preanal organ ( $p o$ ) situated in the anterior margin of anal plates. One pair of lyrifissures $(\mathrm{iad})$ is located anteriorly of adanal setae (ad3) (Figures 1b, 2b, and 3e).

\section{Legs of the Hydrozetes crassipes sp. $n$.}

Each leg from (I-IV) has five segments and carries different shapes and sizes of setae (serrated and simple setae). Tarsus of each leg terminates with one distinct claw (monodactylous) (Figures 2a,b, 3f-h, and 4a-e). Leg II is the shortest and followed by III, I, and IV (Table 1). Formulas of leg setation (famulus included) and solenidia are: leg I (1-5-4-4-17) [1-2-2], leg II (1-5-3-4-15) [1-1-2], leg III (2-4-1-3-13) [1-1-0], leg IV (1-3-2-4-10) [0-1-0].

\section{Measurements of paratype}

The measurements $(\mu \mathrm{m})$ of morphological characters for paratype individuals of the present species Hydrozetes crassipes are summarized in Table " 1 ". Formulas of paratype leg setation and solenidia are mentioned in Table " 2 ".

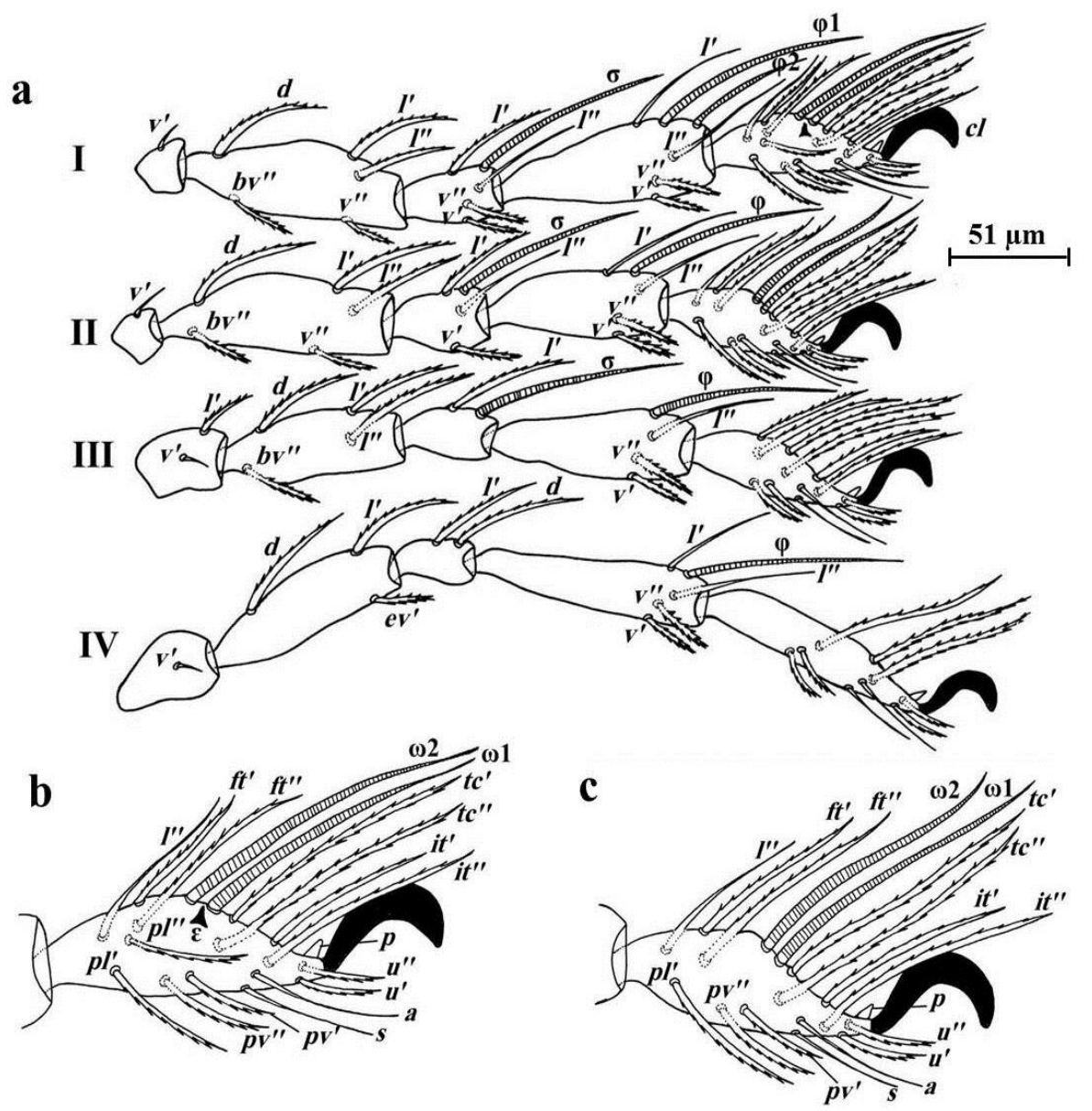

Figure 4. Camera Lucida drawings of the adult female Hydrozetes crassipes sp. n. showing: (a) legs (I-IV), (b-e) higher magnification of (a) showing tarsus of legs I, II, III, and IV, respectively. Single prime (') marks setae on anterior and double prime (") marks setae on posterior side of the given leg segment.

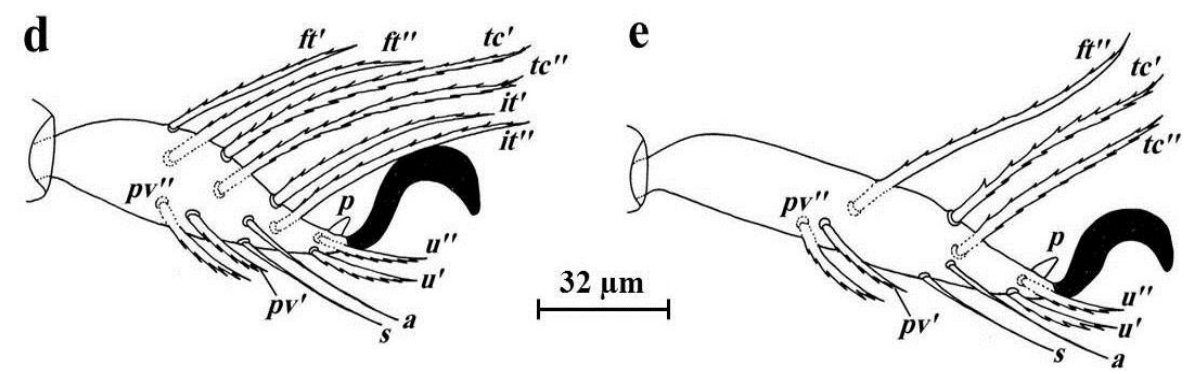


Table 1: Paratype measurements $(\mu \mathrm{m})$ of different morphological characters of adult female Hydrozetes crassipes $\mathrm{sp} . \mathrm{n} .(\mathrm{N}=18)$.

\begin{tabular}{|c|c|c|c|c|c|}
\hline Characters & $\begin{array}{l}\text { Microns } \\
(\mu \mathrm{m})\end{array}$ & Characters & Microns $(\mu \mathrm{m})$ & Characters & $\begin{array}{c}\text { Microns } \\
(\mu \mathrm{m})\end{array}$ \\
\hline Body length & $432-480$ & \multicolumn{2}{|c|}{ Notogaster } & Length of genital opening & $48-56$ \\
\hline Body width & $256-320$ & length & 296-336 & \multicolumn{2}{|l|}{ Length of anal setae } \\
\hline \multicolumn{2}{|l|}{ Prodorsum } & width & $256-320$ & seta $a n 1$ & $12-16$ \\
\hline length & $120-160$ & \multicolumn{2}{|c|}{ Length of notogastral setae } & seta $a n 2$ & $9-14$ \\
\hline width & $144-176$ & seta $c$ & $44-52$ & seta $a d l$ & $10-13$ \\
\hline \multicolumn{2}{|c|}{ Length of prodorsal setae } & seta $l a$ & $42-52$ & seta $a d 2$ & $9-14$ \\
\hline seta ro & $21-29$ & seta $l m$ & $34-52$ & seta $a d 3$ & $9-15$ \\
\hline seta le & $13-21$ & seta $l p$ & $31-47$ & Length of anal opening & $88-112$ \\
\hline seta in & $10-16$ & seta $d a$ & $39-47$ & \multicolumn{2}{|c|}{ Length of coxal epimeral setae } \\
\hline seta $e x$ & $5-10$ & seta $d m$ & $34-52$ & seta $1 a$ & $9-11$ \\
\hline ss & $21-29$ & seta $d p$ & $34-47$ & seta $l b$ & $16-21$ \\
\hline bo & $8-13$ & seta $h l$ & $26-31$ & seta $l c$ & $9-11$ \\
\hline Length of pedipalp & $54-59$ & seta $h 2$ & $26-34$ & seta $2 a$ & $9-10$ \\
\hline \multicolumn{2}{|l|}{ Chelicerae } & seta $h 3$ & $31-39$ & seta $3 a$ & $9-11$ \\
\hline length & $92-96$ & seta $p l$ & $26-31$ & seta $3 b$ & $15-18$ \\
\hline width & $37-42$ & seta $p 2$ & $23-26$ & seta $4 a$ & $18-21$ \\
\hline \multicolumn{2}{|c|}{ Length of cheliceral setae } & seta $p 3$ & $23-26$ & seta $4 b$ & $11-14$ \\
\hline seta $c h a$ & $23-27$ & \multicolumn{2}{|c|}{ Length of genital setae } & seta $4 \mathrm{c}$ & $11-14$ \\
\hline seta $c h b$ & $18-21$ & seta $g 1$ & $16-20$ & Length of legs & \\
\hline \multicolumn{2}{|c|}{ Length of subcapitular setae } & seta $g 2$ & $16-20$ & leg I & $288-304$ \\
\hline seta $h$ & $18-22$ & seta $g 3$ & $16-18$ & leg II & $264-288$ \\
\hline seta $m$ & $14-16$ & seta $g 4$ & $16-20$ & leg III & 272-304 \\
\hline seta $a$ & $12-14$ & seta $g 5$ & $16-19$ & leg IV & $320-352$ \\
\hline adoral setae & $9-11$ & seta $a g$ & $17-20$ & & \\
\hline
\end{tabular}

Table 2: Leg setation and solenidia of adult female Hydrozetes crassipes sp. n.

\begin{tabular}{|c|c|c|c|c|c|}
\hline \multirow{2}{*}{ Leg } & \multicolumn{5}{|c|}{ Segments } \\
\hline & Trochanter & Femur & Genu & Tibia & Tarsus \\
\hline I & $v^{\prime}$ & $d,(l), b v^{\prime \prime}, v^{\prime \prime}$ & $(l),(v), \sigma$ & $(l),(v), \varphi 1, \varphi 2$ & $\begin{array}{l}(f t),(t c),(i t),(u), p, a, s, \\
(p v),(p l), l^{\prime \prime}, \varepsilon, \omega 1, \omega 2\end{array}$ \\
\hline II & $v^{\prime}$ & $d,(l), b v^{\prime \prime}, v^{\prime \prime}$ & $(l), v^{\prime}, \sigma$ & $(l),(v), \varphi$ & $\begin{array}{c}(f t),(t c),(i t),(u), p, a, s, \\
(p v), p l^{\prime}, l^{\prime \prime}, \omega 1, \omega 2\end{array}$ \\
\hline III & $v^{\prime}, l^{\prime}$ & $d,(l), b v^{\prime \prime}$ & $l^{\prime}, \sigma$ & $l^{\prime \prime},(v), \varphi$ & $\begin{array}{c}(f t),(t c),(i t),(u), p, a, s, \\
(p v)\end{array}$ \\
\hline IV & $v^{\prime}$ & $d, l^{\prime}, e v^{\prime}$ & $d, l^{\prime}$ & $(l),(v), \varphi$ & $f t^{\prime \prime},(t c),(u), p, a, s,(p v)$ \\
\hline
\end{tabular}

Roman letters refer to normal setae, Greek letters refer to solenidia (except $\varepsilon=$ famulus). Single prime (') marks setae on the anterior and double prime (") marks setae on the posterior side of a given leg segment. Parentheses refer to a pair of setae. 


\section{DISCUSSION}

According to the diagnostic characters extracted from the keys of families, genera, and species ${ }^{[5,6,10-12,15,16]}$, the present species has the characteristic features of family Hydrozetidae, where the dorsum of individuals is smooth or finely punctate, never granulated or rugose. In addition, the genital and anal openings are separated by a distance equal to or greater than the length of genital opening. Moreover, the legs are monodactylous.

The lamellae are present, ridge-like, slightly convergent and without spines in their apex. The prodorsum of the body is characterized with transverse and longitudinal ridges. The exobothridial setae are mostly very short. Trichobothria (bothridium and sensillus) is present. Sensillus is short and clavate. Palps with setation $0-2-1-3-9(+\omega)$. The solenidion of each palp is bacilliform and located close to $\mathrm{acm}$ seta. The anterolateral margins of notogaster without pteromorphae. The number of the notogastral setae is ranged from thirteen to seventeen pairs of setae. All coxal areas are well defined by carinae in mature adult. These characters are in accordance with the genus Hydrozetes.

\section{The diagnostic characters of the present species}

Host: Aquatic plant, Eichhornia crassipes

The site of infection: Roots of floating aquatic plant

Distribution: River Nile, Sohag Governorate, Egypt

\section{The specific characters of the present} species

1- Two pairs of sclerotized plates in humeral regions

2- Seven sclerotized opisthosomal plates

3- Longitudinal distance between setae of $(l-)$ and $(d-)$ series is not equal

4- Five pairs of genital setae $(g l-g 5)$

5- Three pairs of genital discs

\section{The systematic position of the present species}

$\begin{array}{lll}\text { Phylum: } & \text { Arthropoda } & \text { von Siebold, 1848 } \\ \text { Subphylum: } & \text { Chelicerata } & \text { Heymons, 1901 } \\ \text { Class: } & \text { Arachnida } & \text { Cuvier, 1812 } \\ \text { Subclass: } & \text { Acari } & \text { Leach, 1817 } \\ \text { Superorder: } & \text { Acariformes } & \text { Zakhvatkin, 1952 } \\ \text { Order: } & \text { Sarcoptiforms } & \text { Reuter, 1909 } \\ \text { Suborder: } & \text { Oribatida } & \text { Van der Hammen, 1968 } \\ \text { Superfamily: } & \text { Hydrozetoidea } & \text { Balogh, 1961 } \\ \text { Family: } & \text { Hydrozetidae } & \text { Grandjean, 1954 } \\ \text { Genus: } & \text { Hydrozetes } & \text { Berlese, 1902 } \\ \text { Species: } & \text { crassipes } & \end{array}$

Etymology: The specific name of the present mite species "crassipes" refers to the specific name of the host plant (Eichhornia crassipes).

These diagnostic and specific characters of the present species were compared with those of other species of the same genus ${ }^{[6-10]}$. It was found that the present species has specific characters that separate it from the other previously published species of genus Hydrozetes. Also, the present species is recorded for the first time in the roots of floating aquatic plant, Eichhornia crassipes, which is collected from the Nile River, Sohag, Egypt. So, the present species is considered as new one that should be added to the previously published species. 


\section{LIST OF ABBREVIATIONS}

\begin{tabular}{|c|c|c|c|}
\hline $\begin{array}{l}1 a, 1 b, 1 c, 2 a, 3 a, 3 b, \\
4 a, 4 b, 4 c\end{array}$ & Epimeral setae & im & Notogastral lyrifissure \\
\hline$a d 1-a d 3$ & Adanal setae & in & Interlamellar setae \\
\hline$a g$ & Aggenital setae & $l 1-l 4$ & Legs 1-4 \\
\hline an1-an2 & Anal setae & la & Lamellae \\
\hline ap & Anal plate & le & Lamellar setae \\
\hline bo & Bothridium & lent & Lenticulus \\
\hline $\begin{array}{l}c, l a, l m, l p, d a, d m, d p \\
h 1, h 2, h 3, p 1, p 2, p 3\end{array}$ & Notogastral setae & no & Notogaster \\
\hline cel-ce4 & Coxal epimerae I-IV & $p$ & Pedipalp \\
\hline ch & Chelicera & $p d I, p d I I$ & $\begin{array}{l}\text { Pedotecta I and II, } \\
\text { respectively }\end{array}$ \\
\hline cha, chb & Cheliceral setae & po & Preanal organ \\
\hline $\mathrm{cl}$ & Claw & $p r$ & Prodorsum \\
\hline$c p$ & Circumpedal carinae & $p t$ & Palpal tarsus \\
\hline$c r$ & Cristae & ro & Rostral setae \\
\hline$D$ & Dorsophragmata & sop & $\begin{array}{l}\text { Sclerotized opisthosomal } \\
\text { plates }\end{array}$ \\
\hline dis & Discidia & ss & Sensillus \\
\hline$e x$ & Exobothridial setae & su & Subcapitulum \\
\hline$f$ & Longitudinal furrow & $\mathrm{Tg}$ & Trägårdh’s organ \\
\hline$g$ & Genital plate & tua, tup & $\begin{array}{l}\text { Transverse and longitudinal } \\
\text { prodorsal ridges }\end{array}$ \\
\hline$g 1-g 5$ & Genital setae & $\begin{array}{l}v, e v, b v, l, d, f t, t c, \\
i t, p, u, a, s, p v, p l\end{array}$ & Leg setae \\
\hline$g d$ & Genital discs & $\begin{array}{l}v, l, d, \mathrm{~cm}, \mathrm{acm}, \mathrm{ul}, \\
\text { sul, lt }\end{array}$ & Palpal setae \\
\hline gla & $\begin{array}{l}\text { Opisthonotal gland } \\
\text { opening }\end{array}$ & $\omega$ & Palp and leg solenidion \\
\hline$h, m, a$ & Subcapitular setae & $\sigma, \varphi$ & Leg solenidia \\
\hline iad & Adanal lyrifissure & $\varepsilon$ & Leg famulus \\
\hline
\end{tabular}

FUNDING SOURCE DISCLOSURE

There is no funding for this study, it jointly funded by the authors.

\section{CONFLICT OF INTEREST}

The authors declare no potential financial conflict of interest.

\section{ACKNOWLEDGEMENTS}

The authors would like to thank Prof. Dr. Tarek G. Ismail (Zoology Department, Faculty of Science, Sohag University) for his helpful advices during writing this Paper.

\section{REFERENCES}

[1] Colloff, M. J. and Halliday, R. B. (1998). Oribatid Mites: A Catalogue of Australian Genera and Species.
Monographs on Invertebrate Taxonomy, Volume 6. CSIRO Publishing, Collingwood, Australia.

[2] Krantz, G. W. and Baker, G. T. (1982). Observations on the plastron mechanism of Hydrozetes sp. (Acari, Oribatida, Hydrozetidae). Acarologia, 23(3): 273-277.

[3] Behan-Pelletier, V. and Eamer, B. (2007). Aquatic oribatida: Adaptations, Constraints, Distribution and Ecology. In: Acarology XI: Proceedings of the International Congress (Morales-Malacara, J. B.; Behan-Pelletier. V.; Ueckermann, E. et al., eds.), pp. 71-82. Sociedad Latinoamericana de Acarología, México. 
[4] Schatz, H. and Behan-Pelletier, V. (2008). Global diversity of oribatid mites (Oribatida: Acari: Arachnida). Hydrobiologia, 595: 323-328.

[5] Seniczak, S.; Norton, R. A. and Seniczak, A. (2009). Morphology of Hydrozetes confervae (Schrank, 1781) and $H$. parisiensis Grandjean, 1948 (Acari: Oribatida: Hydrozetidae), and keys to European species of Hydrozetes Berlese, 1902. Zoologischer Anzeiger - A Journal of Comparative Zoology, 248(2): 71-83.

[6] Bayartogtokh, B. and Ermilov, S. G. (2019). A new species of Hydrozetes (Acari: Oribatida, Hydrozetidae) from Ecuador and a key to Neotropical species. Int J Acarol, 45(5): 328-334.

[7] Engelbrecht, C. M. (1974). The genus, Hydrozetes Berlese, 1902 (Oribatei: Acari) in South Africa. Navors nas Mus, Bloemfontein, 3(3): 41-49.

[8] Subías, L. S. (2004). Systematic, synonimical and biogeographical check-list of the world's oribatid mites (Acariformes, Oribatida) (17582002). Graellsia, 60: 3-305.

[9] Seniczak, S. and Seniczak, A. (2009). Hydrozetes longisetosus sp. nov. (Acari: Oribatida: Hydrozetidae) - the most primitive European species of Hydrozetes from Poland. J Nat Hist, 43(15-16): 951-971.

[10] Ermilov, S. G. and Corpuz-Raros, L. (2015). Additions to the Philippine oribatid mite fauna (Acari, Oribatida), with description of two new species. Int J Acarol, 41(7): 606-616.

[11] Weigmann, G. and Deichsel, R. (2006). Acari: Limnic Oribatida. In: Süßwasserfauna von Mitteleuropa, Volume 7/2-1 Chelicerata: Araneae/ Acari I. (Gerecke R., ed), pp. 89112. Springer Spektrum, Berlin, Heidelberg, Germany.

[12] Norton, R. A and Behan-Pelletier, V. M. (2009). Oribatida. In: A Manual of Acarology (Krantz, G. W. and Walter, D. E., eds), pp. 430-564. Texas Tech University Press, Lubbock, TX, USA.

[13] Luxton, M. (1985). Cryptostigmata (Arachnida: Acari) - a concise review. Fauna of New Zealand, 7: 1-106.

[14] Norton, R. A. (1977). A Review of F. Grandjean's System of Leg Chaetotaxy in the Oribatei (Acari) and Its Application to the Family Damaeidae. In: Biology of Oribatid Mites (Dindal, D. L., ed), pp. 33-61. SUNY College of Environmental Science and Forestry, Syracuse, New York, USA.

[15] Balogh, J. (1961). Identification keys of world oribatid (Acari) families and genera. Acta Zool Acad Sci Hung, 7(3-4): 243-344.

[16] Krantz, G. W. and Walter, D. E. (2009). A Manual of Acarology, $3^{\text {rd }}$ Edition. Texas Tech University Press, Lubbock, TX, USA.

\section{How to cite this article:}

Mustafa, A. N. and Ramadan, S. A. (2022). A new species of aquatic oribatid mite "Hydrozetes crassipes sp. n." (Family: Hydrozetidae) from Sohag governorate, Egypt. Egyptian Journal of Zoology, 77: 29-40 (DOI: 10.21608/ejz.2022.112192.1066). 


\title{
"HYDROZETES CRASSIPES SP. N." نوع جديد من الحَلَمْ المائي (فصيلة: (HYDROZETIDAE) من محافظة سوهاج، مصر
}

\author{
أسماء نصر الاين مصطفى، سمية أحمد رمضان \\ قسم علم الحيو ان، كلية العلوم، جامعة سو هاج، سوهاج، جمهورية مصر العربية
}

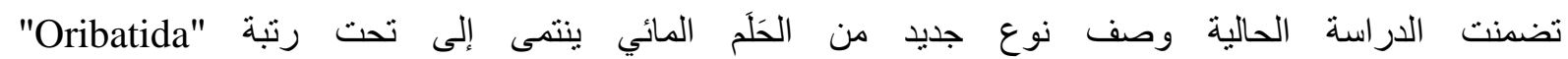

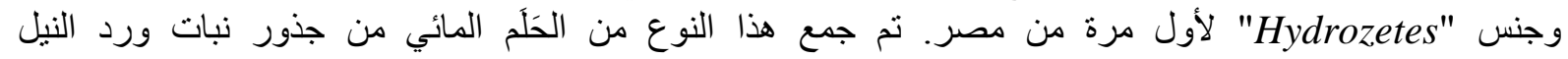

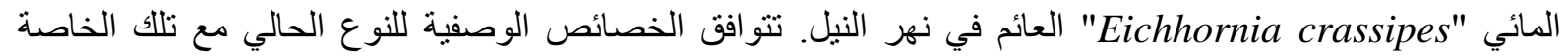

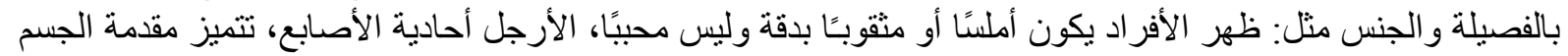

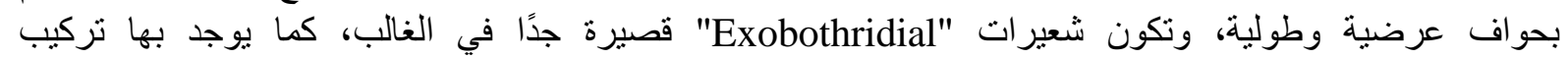

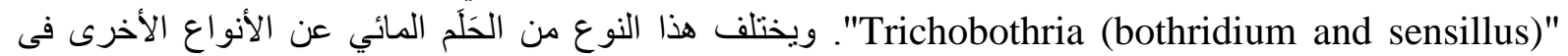
أن منطقة العضد مدعومة بزوجين من الألواح ذات التغلظ الكيتيني وهيَ تنحرف إلى الداخل نحو الصفائح الأمامية

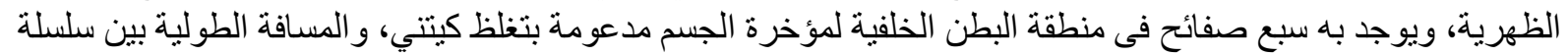

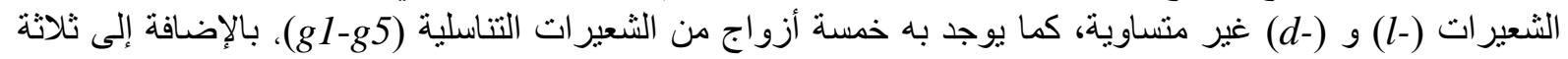
أزواج من الأقر اص التناسلية. 